\title{
STRATEGI PENINGKATAN KESEJAHTERAAN SOSIAL PENYANDANG DISABILITAS NETRA MELALUI KEBIJAKAN INGKLUSIF
}

\author{
${ }^{1}$ Ajie Hanif Muzaqi, ${ }^{2}$ M. Rizki Pratama, ${ }^{3}$ Sugeng Widodo \\ 1,3 Program Studi Administrasi Publik, Fakultas IImu Administrasi Universitas Kadiri. \\ 2 Program Studi Administrasi Publik, Fakultas IImu Administrasi Universitas Brawijaya \\ ajiehanif@unik-kediri.ac.id, Pratamarizkim@ub.ac.id, sugengwidodo@unik-kediri.ac.id \\ Jawa Timur, Indonesia
}

\begin{abstract}
This study aims to determine strategies for improving the social welfare of persons with visual impairments through an inclusive policy implemented by the Malang Blind Social Rehabilitation Technical Implementation Unit (UPT RSCN) Malang as a forum for finding policy forms from the efforts made by the East Java Provincial Government.

The research method used a qualitative approach. The data analysis used to determine the research results used descriptive analysis with an interactive data analysis model. the next process is to identify strengths, weaknesses, opportunities, and threats (SWOT) for the formulation of strategic plans in the context of community empowerment in local government institutions.

The results showed that the strategies implemented in this program were passive and offensive strategies. It can be said that the implementation of the program implemented is quite good, seen from the patient's way of thinking who is more visionary, has work skills and has creativity. In addition, all patients who have been rehabilitated can compete in the world of work and have their own business for their survival. Thus, they can improve regional welfare and reduce unemployment.
\end{abstract}

Keywords: Persons with visually disabilities; Social Welfare; Strategy

\begin{abstract}
Abstrak
Penelitian ini bertujuan untuk mengetahui strategi peningkatan kesejahteraan sosial penyandang disabilitas netra melalui kebijakan inklusif yang dilaksanakan apda Unit Pelaksana Teknis Rehabilitasi Sosial Cacat Netra Malang (UPT RSCN) Malang sebagai wadah dalam menemukan bentuk kebijakan dari upaya yang dilakukan oleh Pemerintah Provinsi Jawa Timur.

Metode penelitian menggunakan pendekatan kualitatif. Analisis data yang digunakan untuk menentukan hasil penelitian menggunakan analisis deskriptif dengan model analisis data interaktif. proses selanjunya adalah mengidentifikasi kekuatan (Strengths), kelemahan (Weaknesses), peluang (Opportunities), dan ancaman (Threats) (SWOT) untuk perumusan rencana strategis dalam konteks pemberdayaan masyarakat di institusi Pemerintah Daerah. Hasil penelitian menunjukan bahwa strategi yang dijalankan dalam program ini adalah strategi pasif dan ofensif. Dapat dikatakan implementasi program yang dilaksanakan cukup baik terlihat dari cara berfikir pasien yang lebih visioner, memiliki skill bekerja dan memiliki kreatifitas. Selain itu, seluruh pasien yang telah di rehabilitasi dapat bersaing di dunia kerja dan memiliki usaha sendiri guna keberlangsungan hidupnya. Dengan demikian, mereka dapat meningkatkan kesejahteraan daerah dan mengurangi angka pengangguran.
\end{abstract}

Kata Kunci: Disabilitas netra; Kesejahteraan sosial; Strategi

Open Access at: http://ojs.uho.ac.id/index.php/PUBLICUHO/index

Journal Publicuho is licensed under a Creative Commons Attribution 4.0 International License. 


\section{PENDAHULUAN}

Pembangunan nasional merupakan suatu usaha pemerintah dalam mensejahterakan masyarakat dan memperbaiki tarag hidup sosil secara adil dan merata. Sebagai usaha untuk mewujudkannya, pembangunan dilakukan di berbagai bidang yang saling berkesinambungan antar satu sama lain. Salah satunya adalah pembangunan sosial kesejahteraan, yakni upaya terarah dan terencana terdiri dari bermacam macam intervensi sosial serta social service untuk kebutuhan hidup yang lebih terpenuhi, permasalahan sosial yang teratasi, dan instutusi-institusi sosial yang semakin kuat. Terdapat kelompok masyarakat yang menjadi prioritas dalam pembangunan ini, yakni masyarakat yang tergolong dalam PMKS (Penyandang Masalah Kesejahteraan Sosial), dan satu diantaranya adalah penyandang disabilitas.

Apabila dilihat data yang diterbitkan Susenas Tahun 2012, penyandang disabilitas netra menempati posisi ke-dua terbanyak dalam kategori masyarakat dengan keterbatasan. Masyarakat dengan keterbatasan penglihatan berjumlah 29,63\% sedangkan lebih dari satu keterbatasan sebesar 39,97\% (Effendi et al., 2019). Melihat kondisi tersebut, pemerintah mulai memberikan perhatian khusus pada kesejahteraan penyandang disabilitas netra. Seperti yang tercantum pada PP Nomor 39 tahun 2012 tentang Penyelenggaraan Kesejahteraan Sosial bahwasanya salah satu penyelenggaraan kesejahteraan sosial dapat dilakukan melalui rehabilitasi sosial. Program rehabilitasi sosial merupakan wujud sinergitas antara pemerintah pusat dengan pemerintah daerah, dimana kebijakan ini sudah ditetapkan oleh Dirjen Rehabilitasi Sosial Kemensos RI yang dikoordinasikan dengan pemerintah daerah di berbagai provinsi.

Sebagai wujud dari implementasi kebijakan inklusif, masyarakat dengan keterbatasan perlu mendapatkan pelayanan publik yang sama. Perhatian akan layanan tersebut perlu dikembangkan baik inovasi dan strategi implementasi dari program. Menurut (Indriyany, 2015) Penyandang cacat/ disabilitas kurang mendapat perlakuan yang layak baik itu berupa pelayanan dari pemerintah ataupun masyarakat. Terabaikannya kepentingan masyarakat difabel dikarenakan negara fokus pada efisiensi dan efektivitas pelayanan semata. Pendapat tersebut diperkuat oleh penelitian yang dilakukan oleh (Harthanti et al., 2015) bahwa bebrapa sekolah jenjang menengah atas di Kabupaten Lombok Timur belum memiliki sekolah khusus. Terlihat bahwa inklusifitas kebijakan belum terimplementasi dengan baik antara Pemerintah Pusat dengan Pemerintah Daerah. Penguatan koordinasi dan strategi pemeberdayaan masyarakat berkubutuhan khusus perlu dikembangkan agar ketahanan sosial masyarakat di Negara ini dapat diperkuat. Tentunya ketahanan sosial dalam dunia pendidikan juga perlu diinklusifkan sebagai awalahn menujua pembangunan yang merata. Kondisi tersebut perlu adanya perbaikan moralitas di tengah masyarakat tentang perlakuan terhadap masyarakat berkebutuhan khusus. Melalui kebijakan secara 


\section{Journal Publicuho}

ISSN 2621-1351 (online), ISSN 2685-0729 (print)

Volume 3 Number 3 (August-October), (2020) pp.381-393

inklusifitas khususnya pelayanan kesejahteraan soial Pemerintah Provinsi Jawa Timur perlu koordinasi dan berinovasi dengan Pemerintah Daerah terkait penanganan masyarakat berkebutuhan khusus di wilayahanya yang dikhususkan pada penyandang disabilitas netra.

Unit Pelaksana Teknis (UPT) yang mengimplementasikan program rehabilitasi sosial untuk pasien penyandang disabilitas netra di wilayah Provinsi Jawa Timur adalah UPT RSCN Kota Malang. UPT ini merupakan tempat untuk mewadahi pasien disabilitas netra untuk mendapatkan pelayanan rehabilitasi sosial agar dapat meningkatkan kesejahteraanya. Adapun UPT ini merupakan produk regulasi dari Pemerintah Provinsi Jawa Timur dalam mendukung program Kementerian Sosial di bidang kesejahteraan penyandang disabilitas netra. Dengan demikian, diperlukan strategi yang tepat dalam pelaksanaannya agar hasil program ini efektif dan terkendali.

Sementara itu, Roebyantho, et al (2010:29) berpendapat bahwa kesejahteraan sosial erat kaitannya pada sebuah fenomena sosial dimana persoalan-persoalan sosial yang terjadi di lingkungan masyarakat dapat diselesaikan secara optimal, terpenuhinya kebutuhan sosial secara memuaskan, terciptanya rasa aman, dan memiliki kesempatan serta kebebasan yang sama dalam bermasyarakat. Seperti yang tertuang dalam Peraturan Pemerintah Nomor 39 tahun 2012 pasal 2 tentang Penyelenggaraan Kesejahteraan Sosial dijelaskan bahwa penyelenggaraan kesejahteraan sosial diprioritaskan pada masyarakat yang hidup di bawah standar kelayakan serta memiliki kriteria masalah sosial diantaranya kemiskinan, keterlantaran, kecacatan, keterpencilan.

Terdapat indikator untuk melihat capaian keberhasilan program pemberdayaan bagi pasien penyandang disabilitas netra dalam rangka peningkatan kesejahteraan sosial yang dikutip dalam (Patria, 2013) diantaranya:

a. Kebutuhan dan kemampuan dasar manusia meningkat meliputi sandang, pangan, papan

b. Terjaminnya kesehatan masyarakat dan pendidikan yang layak;

c. Terciptanya aktivitas sosial yang dinamis; dan

d. Peningkatan pendapatan per kapita

Untuk mencapai keberhasilan sebuah program, diperlukan strategi untuk mencapainya. Pasolong (2010:90) berpendapat bahwa strategi merupakan sebuah tindakan yang terencana secara efektif dan efisien mengandalkan taktik yang sistematik untuk mengatur organisasi mencapai tujuannya. Selaras dengan pendapat tersebut, Marrus yang dikutip dalam Prawirosentono (2014:31) menyatakan jika strategi dapat diterjemahkan sebagai proses penentuan rencana yang dilakukan oleh pimpinan dalam sebuah organisasi dengan berpedoman pada tujaun jangka panjang, diikuti dengan perumusan aksi dan tindakan unntuk mencapai tujuan tersebut. 
Sementara itu, Nawawi (2017:176) berpendapat bahwa terdapat berbagai jenis strategi yang dapat diadaptasi oleh organisasi non-profit, antara lain strategi pasif dan strategi ofensif. Masih menurut Nawawi (2017:177) strategi pasif dijalankan berdasarkan aturan dan regulasi tertentu yang di dalamnya terkandung perintah, petunjuk, pedoman, peraturan. Sedangkan strategi ofensif menurut Nawawi (2017:176) merupakan suatu strategi yang dilakukan dengan membuat berbagai kebijakan dan menyusun tahapannya dengan mengoptimalkan peluang yang ada. Strategi ini umumnya dilaksanakan oleh organisasi nonprofit sebab regulasi yang diciptakan oleh organisasi non-profit lebih dinamis. Oleh sebab itu, untuk strategi ofensif biasanya tidak mematuhi peraturan dan pedoman yang berlaku.

Menurut Peraturan Pemerintah Nomor 39 tahun 2012 tentang Penyelenggaraan Kesejahteraan Sosial pada pasal 3 dijelaskan bahwa penyelenggaraan kesejahteraan sosial harus meliputi rehabilitasi sosial, jaminan sosial, pemberdayaan sosial, dan perlindungan sosial. Dijelaskan pula pada pasal 4 ayat 1 bahwa rehabilitasi sosial dimaksudkan untuk memulihkan dan mengembangkan kemampuan seseorang yang mengalami disfungsi sosial agar tetap mendapatkan fungsi sosialnya secara layak di masyarakat. Kosasih (2012:10) berpendapat bahwa fasilitas rehabilitasi masyarakat memiliki tujuan untuk menciptakan kemampuan bersosialisasi maupun mencegah penurunan kemampuan bersosialisasi bagi individu yang memiliki disfungsi sosial sehingga individu tersebut dapat menjalankan fungsi sosialnya secara utuh. Menurut UPT Pengembangan Tenaga Kesejahteraan Sosial Malang (2013:31) bentuk pendekatan pelayanan rehabilitasi sosial pun terbagi menjadi 3 yakni secara institusional, rehabilitasi dalam lingkup keluarga, dan rehabilitasi bersumber dari swadaya masyarakat.

Berdasarkan Peraturan Menteri Sosial Republik Indonesia Nomor 25 tahun 2012 tentang Standar Rehabilitasi Sosial Penyandang Disabilitas Oleh Lembaga di Bidang Kesejahteraan Sosial menyatakan bahwa rehabilitasi sosial dapat diberikan dalam kegiatan rehabilitasi inklusif. Adapun ke kegiatan rehabilitasi inklusif tersebut dilaksanakan dengan pendekatan yang lebih persuasif serta kekeluargaan. Pada bagian inilah, ranah kebijakan inklusif itu muncul. Konstribusinya tentu dapat lihat pada apakah pelaksana mau atau tidak melakukan rehabilitasi inklusif kepada mereka yang mengalami disfungsi sosial. Seperti disampaikan oleh Thomas R Dye (dalam Wayne Parsons, 2005: xi) "public policy is whatever governments choose to do or not to do" kebijakan publik sebagai "apapun pilihan pemerintah untuk melakukan atau tidak melakukan. Dalam upaya mencapai tujuan negara, pemerintah perlu mengambil pilihan tindakan yang dapat berupa melakukan sesuatu atau tidak melakukan sesuatu. Keduanya, menurut definisi Dye, merupakan kebijakan publik karena merupakan upaya mencapai tujuan tertentu dan keduanya memiliki dampak terhadap masyarakat (Muhammad Elwan, L. O. (2020). 


\section{Journal Publicuho}

ISSN 2621-1351 (online), ISSN 2685-0729 (print)

Volume 3 Number 3 (August-October), (2020) pp.381-393

Dilihat dari latar belakang yang sudah di jelaskan sebelumnya maka penulis akan meneliti tentang bagaimana implementasi dari program perbaikan kesejahteraan bagi penyandang disabilitas netra di UPT RSNC Malang dan bagaimana luaran (output) dari program tersebut. Tujuan dalam penelitian ini ialah menganalisis implemetasi program dan strategi yang dijalankan oleh UPT RSCN Malang. Sedangkan tujuan penelitian ini ialah untuk memberikan masukan inovatif bagi UPT RSCN dalam menjalankan tugas dan fungsinya.

\section{METODOLOGI}

Penelitian ini berjenis penelitian deskriptif melalui pendekatan kualitatif. Penelitian kualitatif merupakan sebuah proses penelitian ilmiah dengan tujuan membedah masalahmasalah yang terjadi di lingkungan sosial dengan objek yang diteliti adalah manusia serta disajikan secara menyeluruh (Herdiansyah, 2010:8). Perspektif pada penelitian kualitatif deskriptif dilaporkan secara lebih terperinci dengan berpedoman pada narsumber kunci untuk mendapatkan data dan fakta tanpa ada intervensi apapun dari peneliti. Sedangkan Fokus dalam penelitian ini ialah: (1) Bentuk-bentuk dan tahapan dalam pelaksanaan program rehabilitasi sosial di UPT RSCN Malang; (2) Jenis-jenis strategi yang diterapkan oleh UPT RSCN Malang dan langkah-langkah dalam mencapai strategi; (3) Indikator keberhasilan program dan hasil (output) program rehabilitasi sosial di UPT RSCN Malang.

Lokasi dalam penelitian ini terletak di Kota Malang sedangan situs penelitian ini terletak di UPT RSCN Malang. Adapaun alasan dilaksanakannya penelitian di lokasi tersebut karena Pemerintah Provinsi Jawa Timur melalui Dinas Sosial membangun fasilitas rehabilitasi bagi penyandang disabilitas netra yang berlokasi di UPT RSCN Malang dalam rangka mendukung program pemerintah pusat. Oleh sebab itu, untuk menggali data dan fakta penelitian terkait program rehabilitasi penyandang disabilitas netra, peneliti perlu mendatangi lokasi tersebut

Analisis data yang digunakan untuk menentukan hasil penelitian menggunakan analisis deskriptif dengan model analisis data interaktif (Saldana et al 2013:2). Analisis deskriptif sediri teridri dari 4 (empat) tahap penggalian data yakni pengumpulan data, kondensasi data, penyajian data, dan penarikan kesimpulan atau diversifikasi. Setelah dilakukan analisis data menggunakan metode kualitatif deksriptif, peneliti perlu melakukan analisis terhadap faktor internal dan eksternal untuk menemukan alternatif strategi. Maka proses selanjunya adalah mengidentifikasi kekuatan (Strengths), kelemahan (Weaknesses), peluang (Opportunities), dan ancaman (Threats) (SWOT) yang menurut Rangkuti (2015:31) terbagi dalam 4 matriks yakni strategi SO, strategi ST, strategi WO, dan strategi WT. Setelah dilakukan analisis deskriptif selanjutnya peneliti merangkumnya dalam bentuk alternatif strategi. Dalam penelitian SWOT deskriptif, hasil analisis SWOT dipakai untuk perumusan rencana strategis dalam konteks pemberdayaan masyarakat di institusi Pemerintah Daerah (Citra, 2017). 


\section{HASIL DAN PEMBAHASAN}

Menurut Dinas Sosial Provinsi Jawa Timur terdapat tiga bentuk pendekatan pelayanan rehabilitasi, yaitu rehabilitasi secara institusional, rehabilitasi bersumber daya masyarakat (RBM), dan rehabilitasi dalam keluarga (RDK). Pelayanan bagi penyandang disabilitas netra di RSCN Malang termasuk dalam bentuk pendekatan pelayanan rehabilitasi sosial secara institusional. Sistem pelayanannya dengan menempatkan penyandang disabilitas netra dalam suatu lembaga pemerintah atau institusi yang memberikan pelayanan di bidang sosial, sehingga penyandang disabilitas netra tidak hanya mendapatkan perawatan secara medis melainkan juga secara mentalnya. Hal tersebut dirasa perlu karena penyandang disabilitas netra memerlukan sebuah pelayanan atau program yang dapat meningkatkan kemampuan bersosialisasi, keberfungsian secara sosial, fisik, dan mental dan tentunya meningkatkan kesejahteraan sosialnya.

Melalui pendekatan pelayanan rehabilitasi sosial secara institusional ini, penyandang disabilitas netra akan mendapatkan pelayanan dalam bentuk sistem panti yang dikelola oleh UPT RSCN Malang, yakni sebuah UPT yang menjalankan sebagian fungsi dari Pemerintah Provinsi Jawa Timur khususnya Dinas Sosial dalam memberikan layanan terhadap penyandang disabilitas netra di Jawa Timur. Panti disini menjadi sarana rehabilitasi sosial bagi seluruh klien, yakni sebagai institusi pemberian layanan kesejahterann sosial yang memiliki wewenang utama untuk meningkatkan kualitas dan kesejahteraan penyandang disabilitas netra agar dapat hidup yang lebih baik kedepannya.

Panti juga dibangun dan dilengkapi dengan berbagai fasilitas maupun sarana pendunkung keberhasilan program rehabilitasi sosial. Layanan yang dilakukan berfokus pada pemenuhan berbagai dimensi yang dibutuhkan oleh penyandang disabilitas netra seperti kebutuhan jasmani, rohani, sosial dan ekonomi. Dalam memberikan pelayanan kepada klien pun harus mengacu pada pedoman seperti Undang-Undang maupun Peraturan Pemerintah yang mengatur mengenai rehabilitasi sosial. Dengan demikian, diharapkan pelaksanaan program rehabilitasi sosial akan terpadu dan mampu mencapai tujuan utamanya, yakni meningkatkan kesejahteraan sosial kelompok masyarakat yang mengalami disfungsi sosial, salah satunya adalah penyandang disabilitas netra.

Sementara itu, administrasi publik merupakan koloborasi yang dilaksanakan oleh lebih dari satu orang serta institusi tertentu dalam melaksanakan berbagai tanggung jawab pemerintah sebagai upaya pemenuhan tuntutan publik secara efektif dan efisien. Public administration juga diartikan sebagai disiplin ilmu dan solusi ketika terjadi suatu permasalahan di publik. Persoalan yang diangkat dalam penelitian ini ialah kesejahteraan sosial para penyandang disabilitas netra dimana hal ini menjadi sebuah masalah publik karena memiliki pengaruh yang luas bagi individu yang bersangkutan maupun masyarakat. Upaya untuk mengatasinya ialah melalui kerjasama pemerintah dengan berbagai pihak 


\section{Journal Publicuho}

ISSN 2621-1351 (online), ISSN 2685-0729 (print)

Volume 3 Number 3 (August-October), (2020) pp.381-393

dengan melaksanakan program rehabilitasi sosial di UPT RSCN Malang. Adanya program tersebut juga menjadi sebuah upaya tersendiri untuk memenuhi kebutuhan publik, khususnya para penyandang disabilitas netra.

Program rehabilitasi sosial di UPT RSCN ini juga merupakan suatu perwujudan kegiatan dari pembangunan kesejahteraan sosial, khususnya penyandang disabilitas netra. Salah satu tujuan pembangunan ialah untuk meningkatkan derajat hidup manusia yang bukan hanya pendapatan, namun yang terpenting pembukaan lapangan kerja yang seluas luasnya, perbaikan layanan dasar seperti pendidikan dan kesehatan, serta perhatian khusus terhadap nilai-nilai budaya dan sosial di masyarakat, dimana seluruh hal tersebut dalam rangka perwujudan kesejahteraan sosial. Program rehabilitasi sosial di UP RSCN juga bertujuan untuk meningkatkan kesejahteraan sosial para penyandang disabilitas netra bukan sekedar meningkatnya pendapatan namun berimplikasi pada penciptaan lapangan kerja baru bagi mereka baik itu dengan berwirausaha maupun penyaluran ke berbagai dunia usaha. Selain itu, tidak hanya berfokus pada kesejahteraan secara materiil saja namun juga dari aspek lainnya seperti perubahan sikap, tingkah laku, dinamika sosial serta kemampuannya dalam bersosialisasi.

Suatu program dirancang untuk mengatasi permasalahan yang terjadi di masyarakat. Sebuah produk kebijakan berupa program memiliki 3 (tiga) unsur penting agar implementasi program dapat dikatakan tercapai. Pertama, apa yang sedang menjadi kebutuhan kelompok sesuai dengan program yang dilaksanakan sehingga program tersebut dapat memberikan manfaat, Kedua penyelenggara/ aktor pelaksana program memiliki kapasitas dan kemampuan sesuai dengan program yang dijalankan. Ketiga, syarat tercapainya luaran program harus sesuai dengan keinginan luaran organisasi dan dapat dilakukan oleh kelompok penerima manfaat.

Berdasarkan hasil penelitian dapat diketahui bahwa implementasi program rehabilitasi sosial di Unit Pelayanan Terpadu Cacat Netra Kota Malang dapat dikatakan terimplentasi dengan baik. Kondisi tersebut terlihat dari kesesuaian program dengan kebutuhan yang memang dibutuhkan oleh penyandang disabilitas netra. Sehingga dengan adanya program tersebut mejadi solusi yang sangat tepat untuk mengurangi permasalahan masyarakat dalam konteks pemberdayaan penyandang disabilitas netra. Melalui program ini mereka tidak hanya mendapatkan penanganan secara medis atau kesehatan saja tetapi juga secara mental dan refungsionalisasi supaya memiliki kemampuan dalam menjalankan fungsi sosial secara normal, sehingga dapat mendukung adanya peningkatan kesejahteraan sosial masing-masing individu.

Pelaksanaan program rehabilitasi sosial di UPT RSCN juga sesuai dengan kemampuan penyelenggara panti, dimana terlihat dari kinerja seluruh pegawai, instruktur, maupun 
pekerja sosial dalam memberikan pelayanan kepada klien. Disamping itu, hal yang menjadi pendukung keberhasilan program rehabilitasi sosial ini ialah sikap dan perilaku dari penyandang disabilitas netra sendiri. Setelah mendapatkan pelayanan rehabilitasi sosial, mereka menunjukkan perubahan yang signifikan mulai dari perubahan sosial dan peningkatan kesejahteraan sosialnya. Sehingga dapat disimpulkan jika program rehabilitasi sosial di UPT RSCN Malang ini sudah cukup berhasil.

Program rehabilitasi sosial bertujuan untuk meningkatkan dan mencegah penurunan kemampuan bersosialisasi agar penyandang disabilitas dapat menjalankan fungsi sosialnya dengan wajar. Selaras dengan pendapat diatas, Peraturan Pemerintah Nomor 39 Tahun 2012 tentang Kesejahteraan Sosial juga telah menyebutkan bahwa penyelenggaraan rehabilitasi sosial bertujuan untuk memulihkan dan mengembangkan kemampuan individu yang mengalami disfungsi sosial agar dapat melaksanakan fungsi sosialnya dengan wajar.

Tujuan tersebut selaras dengan tujuan penerapan kebijakan rehabilitasi sosial yang berlokasi di UPT RSCN, dimana kebijakan rehabilitasi sosial tersebut dapat merubah cara berfikiri pasien yang negatif menjadi positif. Cara berfikir yang negatif membuat klien selalu merasa ketakutan akan masa depan yang tidak akan sejahtera dan juga kekhawatiran karena selalu bergantung pada orang lain baik itu dalam aktivitas sehari-hari maupun pemenuhan kebutuhan hidupnya. Hal tersebutlah yang membuat mereka tidak percaya diri, terlebih lingkungan di sekitarnya yang belum bisa memberi perlakuan yang sama dengan penuh. Dampaknya, mereka akan sulit berkomunikasi maupun bersosialisasi dengan orang lain dan tidak bisa menyalurkan fungsi sosialnya dengan wajar. Dengan demikian, tujuan pelaksanaan program rehabilitasi sosial UPT RSCN sudah bagus karena dapat meningkatkan kemampuan bersosialisasi serta mencegah adanya penurunan kemampuan bersosialisasi masing-masing klien agar nantinya dapat bergabung dengan masyarakat.

Selain itu rehabilitasi sosial juga berperan penting untuk mencegah kondisi fisik, mental maupun sosial individu yang bersangkutan menjadi lebih buruk dari sebelumnya. Dalam Peraturan Pemerintah Nomor 39 juga tercantum bahwa selain mencegah, rehabilitasi sosial juga bertujuan untuk mengatur ulang fungsi penyandang disabilitas secara fisik, psikis, dan lingkungan sekitarnya serta meningkatkan kreatifitas penyandang disabilitas. Maka dapat dipahami jika melalui program rehabilitasi sosial diharapkan masing-masing individu yang bersangkutan tidak hanya dapat melaksanakan fungsi dan peran sosialnya di masyarakat, tetapi fisik dan mental mereka juga harus berfungsi dengan baik dan wajar. Disamping itu, dengan mengikuti program rehabilitasi sosial para penyandang disabilitas memiliki kemampuan untuk terampil dan kreatif yang dapat dijadikan modal utama bersosial dan bermasayarakat secara normal.

Hal tersebut juga sesuai dengan cita-cita dan harpan penerapan program rehabilitasi sosial yang telah disusun oleh UPT RSCN, yaitu supaya penyandang disabilitas netra dapat 


\section{Journal Publicuho}

ISSN 2621-1351 (online), ISSN 2685-0729 (print)

Volume 3 Number 3 (August-October), (2020) pp.381-393

mandiri dan memiliki keterampilan. Adanya berbagai bimbingan seperti braille, activity daily living, olahraga serta bimbingan sosial dan spiritual dapat meningkatkan keberfungsian sosial, fisik dan mental mereka, sehingga tidak akan bergantung lagi pada orang lain dalam memenuhi kebutuhan hidupnya. Klien juga diberikan bimbingan keterampilan agar mereka dapat memiliki bekal untuk bekerja, dengan demikian setelah lulus dari UPT RSCN mereka dapat bekerja sesuai kemampuan yang dimilikinya.

Berdasarkan hasil penelitian dapat dilihat bahwa tujuan yang telah dirumuskan oleh UPT RSCN sudah sangat tepat dan sesuai dengan kondisi penerima pelayanan yang diharapkan. Terlebih tujuan utama dari pelaksanaan program rehabilitasi sosial ialah adanya peningkatan kondisi kesejahteraan dari masing-masing klien, baik itu terpenuhinya kebutuhan hidup maupun kebutuhan sosial dan spiritual. Adanya tujuan yang tepat akan mendukung keberhasilan program rehabilitasi sosial di UPT RSCN, karena menjadi sebuah pedoman dalam menjalankan kegiatannya sehingga pemberi pelayanan akan mengetahui dengan jelas pelayanan seperti apa yang akan diberikan kepada klien. Disisi lain, tujuan tersebut juga memudahkan pihak UPT RSCN dalam menentukan atau mengetahui hasil akhir yang diinginkan terhadap klien, sehingga selain dapat membantu organisasi untuk meraih kinerja yang tinggi, juga mampu meningkatkan kapabilitas organisasi untuk mendapatkan dukungan dan sumberdaya yang dibutuhkan di sekitarnya.

\section{Bentuk-bentuk dan tahapan dalam pelaksanaan program rehabilitasi sosial di UPT RSCN Malang}

Pelaksanaan program rehabilitasi sosial di UPT RSCN Malang dilakukan dalam 11 bentuk, yakni motivasi, pelayanan sosial, pelayanan aksesibilitas, bimbingan keterampilan, bimbingan fisik, bimbingan resosialisasi, bimbingan mental dan keagamaan, konseling, rujukan, bantuan stimulan, dan pemberdayaan atau pembinaan lanjut alumni. Sedangkan kegiatan pada pelaksanaan program diterapkan sesuai pedoman supaya lebih terencana dan optimal. Tahapannya dimulai dengan tahap pendekatan sebagai awalan, pada tahap ini memiliki kegiatan pemberian orientasi yang dibarengi dengan motivasi, konsultasi, identifikasi, dan seleksi. Setelah tahap penerimaan, klien akan segera ditempatkan dalam asrama dan mendapatkan beberapa peralatan kegiatan sehari-hari. Seain itu kegiatan yang tak kalah penting dalam tahapan ini adalah penelaahan dan pengungkapan serta penempatan dalam program.

Setelah itu, klien akan masuk dalam tahapan bimbingan sosial dan keterampian, dimana mereka akan mendapatkan pendampingan secara fisik dan psikis seperti pendampingan keruhanian, jasmani, dan segala macam aktivitas sehari hari (activity daily living). Selanjutnya bimbingan sosial seperti BTB, bahasa indonesia, berhitung, budi pekerti, kewiraswastaan, serta bimbingan keterampilan usaha seperti handicraft, industry berskala rumahan, pijat, seni 
musik dan qiro'at. Tahap berikutnya adalah penempatan dalam masyarakat dimana klien wajib mengikuti PBK di berbagai dunia usaha yang telah bermitra dengan UPT RSCN selama 1 bulan. Setelah itu, klien akan mengikuti tahap terakhir yakni pembinaan lanjut yang terdiri dari monitoring, konsultasi, dan evaluasi.

\section{Jenis-Jenis Strategi Yang Diterapkan Oleh UPT RSCN Malang dan Langkah-Langkah Mencapai Strategi}

Jenis upaya atau strategi yang dilaksanakan oleh UPT RSCN dalam rangka meningkatkan kesejahteraan pasiennya yang di rehab adalah strategi pasif dan ofensif Strategi pasif yang diterapkan yakni membuat rencana dan tindakan yang sesuai dengan pedoman dan perundang-undangan yang berlaku melalui pemberian pelayanan secara bertahap, pendekatan secara individu, pemberian bimbingan lanjut atau bantuan bagi seluruh alumni, pemenuhan sumber daya manusia dalam panti serta pemenuhan sarana dan prasarana.

Sedangkan strategi ofensif yang diterapkan yakni dengan membuat rencana dan tindakan yang selalu memanfaatkan semua peluang yang ada, baik itu dari dalam lingkungan panti maupun lingkungan eksternal. Strategi tersebut dijalankan dengan cara mengenalkan problematika penyandang disabilitas netra dan panti rehabilitasi sosial kepada masyarakat, melibatkan penyandang disabilitas netra dalam acara atau lomba tertentu, peningkatan kompetensi dan profesionalisme penyelengara panti, kerjasama dengan berbagai pihak serta pemilihan lokasi rehabilitasi sosial.

Terdapat langkah utama yang ditempuh oleh UPT RSCN dalam mencapai strategi untuk meningkatkan kesejahteraan penyandang disabilitas netra, yakni merumuskan visi dan misi. Dengan merumuskan visi dan misi, mengidentifikasi kondisi internal dan eksternal lingkungan dengan melihat faktor pendorong dan faktor penghambat implementasi program, perumusan berbagai strategi yang dapat dijalankan, pengkajian dan evaluasi tiap-tiap strategi yang sebelumnya telah dirumuskan, dan menentukan strategi yang paling tepat diantara alternatif strategi lainnya untuk meraih tujuan baik dalam jangka pendek maupun jangka panjang.

3. Indikator keberhasilan program dan hasil (output) Program Rehabilitasi Sosial di UPT RSCN Malang

UPT RSCN telah menetapkan indikator keberhasilan klien yang dilihat dari aspek sikap dan aspek akademis. Jika dilihat dari aspek akademis klien haruslah memiliki tata krama dan sopan santun yang baik, memiliki sikap disiplin dan tanggung jawab terhadap diri sendiri maupun lingkungannya, memiliki prinsip yang kuat dalam hidup, dan memiliki kepercayaan diri. Sedangkan jika dilihat dari aspek akademis klien harus mampu mandiri, dapat bersosialisasi dan beradaptasi dengan lingkungannya, memiliki kapabilitas dalam menjalankan fungsi sosialnya secara normal di masyarakat agar berdampak pada kesempatan kerja yang dimilikinya. 


\section{Journal Publicuho}

ISSN 2621-1351 (online), ISSN 2685-0729 (print)

Volume 3 Number 3 (August-October), (2020) pp.381-393

Setelah menjalani program rehabilitasi sosial di UPT RSCN, para penyandang disabilitas netra yang menjadi klien mengalami banyak perubahan seperti perubahan pola pikir yang awalnya negatif menjadi positif, rasa kepercayaan diri yang semakin meningkat dan terkikisnya rasa kekhawatiran akan masa depan yang akan dijalaninya. Adanya perubahan dalam mindset mereka juga meningkatkan kemampuan mereka dalam bersosialisasi sehingga kehadirannya di lingkungan masyarakat tidak akan diremehkan. Disamping itu, melalui berbagai bimbingan yang diajarkan, seluruh klien dapat bermobilitas, melakukan aktivitas sehari-hari secara mandiri.

Disamping itu, saat ini klien juga mampu mengembangkan minat dan bakat sesuai yang diinginkannya seperti menyalurkan hobinya dalam bermusik, olahraga, hadrah, dan lain-lain. Namun yang paling utama ialah saat ini mereka telah memiliki keahlian kerja yang menjadi bekalnya untuk bekerja. Hingga saat ini banyak sekali prestasi yang telah diraih baik dalam bidang kesenian, musik, maupun olahraga. Bukan hanya itu, pasien pasca rehabilitasi tidak ada satupun yang tidak bekerja/ menganggur sebab secara masyoritas mereka mendapatkan profesi baru yaitu berwirausaha. Oleh karena itu, sebagian besar pasien pasca rehabilitiasi dapat meningkatkan taraf hidup dan derajat kesejahterannya serta dapat memberikan kebermanfaatan bagi lingkungan sekitarnya.

\section{Hasil Program Rehabilitasi Sosial di UPT RSCN Malang}

Tujuan utama dari pelaksanaan program rehabilitasi sosial di UPT RSCN Malang sudah sangat jelas, yakni untuk meningkatkan kondisi kesejahteraan sosial penyandang disabilitas netra. Kehidupan atau keadaaan sejahtera yang harus dicapai tidak hanya tercukupinya segama macam tuntutan hidup sifatnya mendasar seperti sandang, pangan, papan dan berbagai pelayanan sosial, namun juga kebutuhan sosial dan spiritual. Sehingga untuk mengetahui hasil program rehabilitasi sosial bagi penyandang disabilitas netra, peneliti memfokuskan hal kepada 5 (lima) aspek, yaitu : (1) Progresivitas dalam perbaikan individu maupun sekelompok orang untuk menjadi lebih baik; (2) Pengembangan SDM; (3) Berimplikasi terhadap adaptasi diri dan perubahan sosial; (4) Terciptanya semangat berkomunitas untuk tujuan pembanggunan; (5) Penyediaan sistem yang terstruktur dimana fungsinya memberikan pelayanan yang terorganisir di seluruh institusi

Kesejahteraan sosial merupakan sebuah sistem yang tertata dan terorganisir dari berbagai aktivitas yang tujuannya untuk memberi peluang setiap individu atau kelompok masyarakat dapat menanggulangi masalah sosial. Dengan demikian, melalui ke-lima fungsi tersebut bisa diketahui bagaimana pelaksanaan program rehabilitasi sosial yang telah diberikan mampu memberikan dampak (output) yang signifikan terhadap penyandang disabilitas netra, khususnya dalam hal ini ialah peningkatan kesejahteraan sosial. Namun pada konteks ini bukan hanya sekedar mengerti tentang peningkatan kesejahteraan sosial 
yang dialami oleh klien di UPT RSCN, tetapi juga kondisi perubahan sosialnya setelah mengikuti program rehabilitasi sosial.

Berdasarkan hasil penelitian dapat diketahui jika melalui kebijakan rehabilitasi sosial ini para pasien disabilitas netra dapat memenuhi hak dan kewajibannya seperti yang tercantum pada Undang-Undang Nomor 4 Tahun 1997 tentang Penyandang Cacat. Beberapa hak dan kewajiban tersebut meliputi memperoleh pekerjaan dan penghidupan yang layak sesuai dengan kemampuan yang dimiliki, aksesibilitas dalam pelayanan maupun berbagai fasilitas umum, menumbuhkembangkan bakat dan kemampuannya khususnya pada kemampuan bersosialisasi serta tidak adanya diskriminasi dari lingkungannya ketika terjun ke masyarakat.

\section{KESIMPULAN}

1. Pelaksanaan program rehabilitasi sosial di UPT RSCN telah sesuai dengan standar yang telah ditentukan yakni Peraturan Menteri Sosial Nomor 25 tahun 2012 tentang Standar Rehabilitasi Sosial Penyandang Disabilitas Oleh Lembaga di Bidang Kesejahteraan Sosial. Penyelenggaraan program yang sesuai dengan pedoman mendorong keberhasilan pelayanan yang diberikan kepada klien.

2. Strategi yang telah dirumuskan oleh UPT RSCN sudah terlaksana dengan baik, hal tersebut dapat tercermin dari hasil (output) dari program. Namun sayangnya strategi tersebut belum sepenuhnya dapat beradaptasi dengan lingkungan eksternal. Hal tersebut terlihat dari kurangnya inovasi dalam mengembangkan materi bimbingan khususnya pada bimbingan keterampilan.

3. Indikator keberhasilan yang telah ditetapkan oleh UPT RSCN sudah tercapai dengan baik oleh para klien, disamping itu hasil dari program rehabilitasi sosial di UPT RSCN ini sUdah sangat baik, dimana klien mampu memenuhi hak dan kewajibannya serta utamanya adalah peningkatan kesejahteraan hidupnya.. 


\section{Journal Publicuho}

ISSN 2621-1351 (online), ISSN 2685-0729 (print)

Volume 3 Number 3 (August-October), (2020) pp.381-393

\section{DAFTAR PUSTAKA}

Citra, I. P. A. (2017). Strategi Pemberdayaan Masyarakat Untuk Pengembangan Ekowisata Wilayah Pesisir Di Kabupaten Buleleng. Jurnal IImu Sosial Dan Humaniora, 6(1), 31.

Effendi, L., Apsari, N. C., \& Raharjo, S. T. (2019). Proses Pelaksanaan Rehabilitasi Sosial Disabilitas Netra Di Panti Pelayanan Sosial Disabilitas Penganthi Temanggung Jawa Tengah. Share: Social Work Journal, 8(2), 170.

Harthanti, D., Tani, L. K., \& Syamsiar, H. (2015). Strategi Pemberdayaan Masyarakat Inklusi Berbasis Ketahanan Sosial. Jurnal EducatiO, 10(1), 84-100.

Herdiansyah, Haris. 2012. Metodologi Penelitian Kualitatif Untuk IImu-IImu Sosial. Jakarta: Salemba Humanika.

Indriyany, I. A. (2015). Pelayanan Publik dan Pemenuhan Hak Difabe: Studi tentang Layanan Pendidikan Inklusif Melalui Kasus Pemindahan Difabel dari Sekolah Reguler ke Sekolah Luar Biasa di Yogyakarta. Jurnal Inklusi, 2(1), 1.

Irwanto, et al. 2010. Analisis Situasi Penyandang Disabilitas Di Indonesia: Sebuah Desk-Review. Depok: Pusat Kajian Disabilitas Fakultas IImu-IImu Sosial dan Politik Universitas Indonesia.

Kosasih. 2012. Cara Bijak Memahami Anak Berkebutuhan Khusus. Bandung: Yrama Widya.

Muhammad Elwan, L. O. (2020). Analisis Kebijakan Pajak Daerah Sebagai Sumber Pendapatan Asli Daerah Kabupaten Kolaka Timur Di Era Otonomi Daerah. Journal Publicuho, 3(2), 247. https://doi.org/10.35817/jpu.v3i2.12529

Nawawi, Hadari H. 2017. Manajemen Strategik Organisasi Non-Profit di Bidang Pemerintahan Cetakan ke 5. Yogyakarta: Gadjah Mada University Press.

Pasolong, Harbani. 2012. Metode Penelitian Administrasi Publik. Bandung: Alfabeta.

Patria, S. (2013). Pemberdayaan Penyandang Cacat Netra Melalui Pendidikan Dan Pelatihan Di UPT RSCN Malang. Jurnal Ilmiah Mahasiswa FEB, 2(1), 1-12.

Peraturan Pemerintah Nomor 39 Tahun 2012 tentang Penyelenggaraan Kesejahteraan Sosial.

Peraturan Menteri Sosial Nomor 25 Tahun 2012 tentang Standar Rehabilitasi Sosial Penyandang Disabilitas Oleh Lembaga Di Bidang Kesejahteraan Sosial.

Prawirosentono, Suyadi. 2014. Manajemen Stratejik dan Pengambilan Keputusan Korporasi. Jakarta: Bumi Aksara.

Rangkuti, Freddy. 2015. Analisis SWOT Teknik Membedah Kasus Bisnis: Cara Perhitungan Bobot, Rating dan OCAI. Jakarta: PT. Gramedia Pustaka Utama.

Roebyantho, Haryati. 2012. Evaluasi Program Asistensi Sosial Orang Dengan Kecacatan Berat (Studi Kasus di Kabupaten Kulon Progo dan Kota Banjarmasin). Jakarta: P3KS Press.

Saldana, Johnny, et al., 2013. Qualitative Data Analysis-Third Edition. London: Sage Publication Ltd.

UPT Pengembangan Tenaga Kesejahteraan Sosial Malang. 2013. Kurikulum dan Modul Pendampingan Panca. Malang: Tanpa Penerbit 